\title{
Absence of Juxtaglomerular Cells in the Kidneys of Freshwater Stingrays and Primitive Bony Fishes*1
}

\author{
Mikio Oguri*2
}

(Accepted March 20, 1986)

\begin{abstract}
The juxtaglomerular (JG) cells in the mammalian kidneys are known to secrete a kidney hormone called renin. JG cells are present also in the kidneys of holocephalian and teleostean fishes. However, the kidneys of cyclostomes and elasmobranchs are lacking in these cells. The present histological investigations using Bowie's stain were performed to clarify whether or not JG cells are present in the kidneys of South American freshwater stingrays Potamotrygon spp., the sterlet Acipenser ruthenus, the bester (intergeneric hybrid of $A$. ruthenus $\sigma^{*} \times H$ uso huso ?), and the longnose gar Lepisosteus osseus. However, JG cells were not detectable in the kidneys of any these fishes investigated.
\end{abstract}

Juxtaglomerular (JG) cells of the mammalian kidney are known to secrete renin, a kidney hormone, playing important roles in the blood pressure, aldosterone secretion and water intake. $^{1,2)}$ These cells are also present in the kidneys of lower vertebrates such as teleosts ${ }^{2-11)}$ and holocephalans. ${ }^{2,12,13)}$ However, JG cells are absent in the kidneys of cyclostomes and marine elasmobranchs. ${ }^{2-4,14-16)}$

As for the primitive bony fishes, some contradictory findings are reported in the previous studies.7,12) JG cells have been investigated hitherto using six species of these primitive bony fishes and their absence has been reported in five species. $^{B, 7,12)}$ However, in one species, longnose gar (Lepisosteus osseus), absence of JG cells and their presence have been reported by Ogawa et $a l^{7)}$ and Nishimura et al., ${ }^{12)}$ respectively.

To reexamine this contradictory finding, the present investigation was carried out, using three species of the primitive bony fishes, including the longnose gar. Reinvestigation was also done on the absence of JG cells in the freshwater stingrays, which were examined previously ${ }^{14,15}$ using limited materials. So, the present paper deals with the both results obtained.

\section{Materials and Method}

The fish species used in the present examination are as follows; freshwater stingrays Potamotrygon spp. (6 specimens, 98-187 $\mathrm{g}$ in body weight), sterlet Acipenser ruthenus (4 specimens, 7-11 g), bester (intergeneric hybrid of $A$. ruthenus o $\times$ Huso huso +, 3 specimens, $325-465 \mathrm{~g}$ ), and longnose gar L. osseus (6 specimens, 70-120 g). Freshwater stingrays were obtained from Tokyo Aquarium Co. Ltd. Bester was supplied from Mie Prefectural Inland Fisheries Experimental Station, Komono. Sterlet and longnose gar were purchased from a fish dealer in Nagoya City. In the present paper, I report the scientific name of the freshwater stingrays only as $P$. spp. because of the confused taxonomic status in the genus Potamotrygon, ${ }^{17,18}$ ) and of no available information on the collecting stations of these stingrays in the South American rivers, which is necessary to identify fish species.

From these fishes several portions of the kidneys were removed and fixed in Helly's fluid. After ethanol dehydration, these fixed kidney tissues were embedded in paraffin and sectioned at a thickness of 6 to $7 \mu \mathrm{m}$. The sections were stained with Bowie's method for the demonstration of JG cells or Mayer's acid hemalum and eosin for general light microscopy.

\section{Results and Discussion}

Careful examinations were carried out on the kidney of the South American freshwater stingrays $P$. spp., but the JG cells were not detectable in the vicinity of renal glomeruli (Fig. 1). The

\footnotetext{
*1 The outline of this report was presented at the annual meeting of the Japanese Society of Scientific Fisheries, Tokyo, April, 1986.

*2 Laboratory of Fish Biology, Faculty of Agriculture, Nagoya University, Nagoya 464, Japan (小栗幹郎; 名古屋大学蜄学部)
} 
same result has been reported in our previous study on the absence of JG cells in the kidney of cyclostomes and elasmobranchs. ${ }^{14,15)}$ In this study, ${ }^{14,157}$ we could examine the kidney of the freshwater stingray $P$. circularis provided kindly by Dr. T. B. Thorson, University of Nebraska, U.S.A. But, available kidneys were only from two specimens of the stingray. Thus, investigation on more number of specimens was necessary to get definite conclusion on their absence. So, in the present study I tried reexamination on the absence of JG cells using six specimens of the freshwater stingrays, which are now available as living fish imported from the South America. However, the result of the investigation was the same as in the previous examination ${ }^{14,15)}$ and the JG cells could not be observed in the kidney of the freshwater stingrays, which are similar to freshwater teleosts in viewpoint of body fluid. ${ }^{10,20}$ ) Crockett et al. ${ }^{16)}$ have briefiy reported also the absence of JG cells in the kidney of freshwater stingray $P$. motoro. Accordingly, it is now concluded that the JG cells are absent in the kidney of freshwater stingrays, as well as in the kidney of marine elasmobranchs, even though the renin-like substance seems to be contained in the kidney of the dogfish Scyliorhinus canicula. ${ }^{21)}$

Also, detailed observations on the kidney tissue were made using the sterlet, the bester and the longnose gar. However, JG cells could not be detected in the wall of small blood vessels near the renal glomeruli of these three species of primitive bony fishes (Figs. 2-4). During this examination, I noticed that kidney observation on these primitive bony fishes should be careful, because abundant granulocytes detectable in their interstitial tissue are also stainable in bluish-purple, purplish-red or red colour with Bowie's method (Figs. 2-4). When these granulocytes are located closely to the small blood vessels near the renal glomeruli, misidentification as JG cells must be avoided. Krishnamurthy and $\mathrm{Bern}^{\mathrm{\theta})}$ reported the absence of JG cells in the kidney of the Pacific coast white sturgeon Acipenser transmontanus. Furthermore, Ogawa et al. ${ }^{7)}$ and Nishimura et $a l{ }^{12)}$ reported also the absence of JG cells in the kidney of the following four species of primitive bony fishes, bowfin Amia calva, shortnose sturgeon A. brevirostris, Nile bichir Polypterus senegalus, and reed fish Calamoichthys calabaricus. On the other hand, as for JG cells in longnose gar $L$. osseus, the results of the previous examinations are contradictory; the absence of JG cells was de- scribed by Ogawa et al., ${ }^{7)}$ and their presence was reported by Nishimura et al. ${ }^{12}$ However, the results of the present study is in accordance with the former result ${ }^{7)}$ and the JG cells could not be detected in the kidney of longnose gar $L$. osseus.

\section{Acknowledgements}

I wish to thank Mr. A. Muranushi, Director, and staff of Mie Prefectural Inland Fisheries Experimental Station for kindly providing me with the bester. I am also grateful to Mrs. K. Koga for her excellent technical assistance.

\section{References}

1) P. J. Bentley: Comparative Vertebrate Endocrinology, 2nd ed., Cambridge Univ. Press, Cambridge, 1982, pp. 95 and 312.

2) J. X. Wilson: Endocrine Rev., 5, 45-61 (1984).

3) A. Bohle and F. Walvig: Klin. Wochenschr., 42, 415-421 (1964).

4) S. V. Capréol and L.E. Sutherland: Can. J. Zool., 46, 249-256 (1968).

5) M. Oguri and H. Sokabe: Bull. Japan. Soc. Sci. Fish., 34, 882-888 (1968).

6) V. G. Krishnamurthy and H, A. Bern: Gen. Comp. Endocrinol., 13, 313-335 (1969).

7) M. Ogawa, M. Oguri, H. Sokabe, and H. Nishimura: Gen. Comp. Endocrinol., Suppl., 3, 374 380 (1972).

8) M. Oguri, M. Ogawa, and H. Sokabe: Bull. Japan. Soc. Sci. Fish., 38, 195-200 (1972).

9) M. Oguri: Bull. Japan. Soc. Sci. Fish, 46, 295297 (1980).

10) M. Oguri: Bull. Japan. Soc. Sci. Fish., 47, 453455 (1981).

11) J. A. Christensen, S. Knutsson, and A. Bohle: Kidney Int., Suppl., 12, S179-S184 (1982).

12) H. Nishimura, M. Ogawa, and W. H. Sawyer: Am. J. Physiol, 224, 950-956 (1973).

13) M. Oguri: Gen. Comp. Endocrinol, 36, 170-173 (1978).

14) H. Nishimura, M. Oguri, M. Ogawa, H. Sokabe, and M. Imai: Am. J. Physiol., 218, 911-915 (1970).

15) M. Oguri, M. Ogawa, and H. Sokabe: Bull. Japan. Soc. Sci. Fish., 36, 881-884 (1970).

16) D. R. Crockett, J. W. Gerst, and S. Blankenship: Comp. Biochem. Physiol., 44A, 673-675 (1973).

17) R. W. Griffith, P. K. T. Pang, A. K. Srivastava, and G. E. Pickford: Biol. Bull., 144, 304-320 (1973).

18) T. B. Thorson and D. E. Watson: Copeia, 1975, $701-712$ (1975).

19) T. B. Thorson, C. M. Cowan, and D. E. Watson: Science, 158, 375-377 (1967).

20) M. Ogawa and T. Hirano: Zool. Mag., 91, 101105 (1982).

21) I. W. Henderson, J. A. Oliver, A. McKeever, and $N$. Hazon: in "Advances in Animal and Comparative Physiology" (ed. by G. Pethes and V. L. Frenyó), Pergamon, Oxford, 1981, pp. 355-363. 


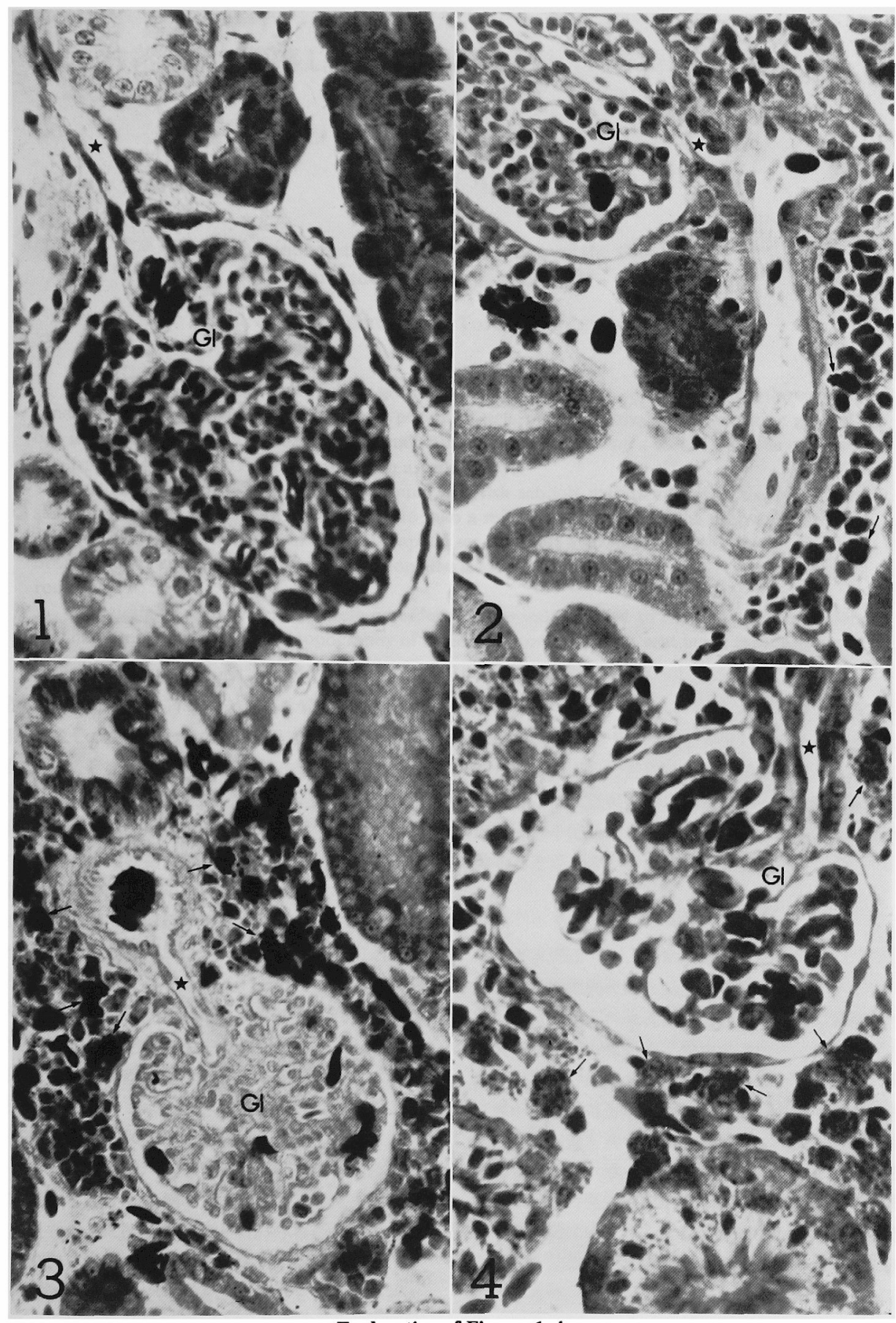

Explanation of Figures 1-4

Fig. 1. Kidney tissue of the South American freshwater stingray Potamotrygon sp. $\times 415$

Figs. 2-4. Kidney tissues of the primitive bony fishes.

Fig. 2. Sterlet Acipenser ruthenus. $\times 600$

Fig. 3. Bester, intergeneric hybrid of $A$. ruthenus $\delta \times$ Huso huso $9 . \quad \times 480$

Fig. 4. Longnose gar Lepisosteus osseus. $\quad \times 930$

G1: glomerulus. Arrow and star indicate Bowie-positive granulocyte and afferent arteriole, respectively. Helly's fluid and Bowie's stain. 